Det er brukt eit tenkt pasientkasus for å illustrere gangen ved skjematerapi, men det bidreg ikkje til å belyse teorien på ein meiningsfull måte. Boka blir rett og slett litt for tynn, bokstaveleg tala.

Jeanette Bjørke-Bertheussen

Psykiatrisk divisjon

Stavanger universitetssjukehus

\section{Nyttig om den muslimske pasient}

Aziz Sheikh, Abdul Rashid Gatrad Caring for muslim patients

2. utg. 158 s, tab, ill. Oxon: Radcliffe, 2008. Pris GBP 25

ISBN 978-1-85775-8122

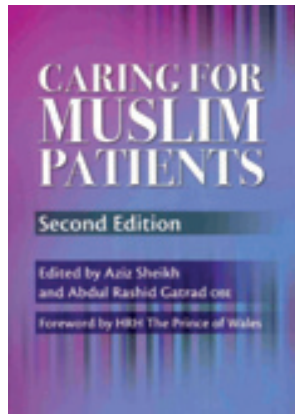

Målgruppen er medisinsk personell, fortrinnsvis ikke-muslimer, som har å gjøre med muslimer i sitt daglige arbeid. Utgangspunktet er hvordan kroppslige og mentale, her religiøse, prosesser kan spille sammen både som årsak til sykdom, i hvordan pasienter opplever sin sykdom, og hvordan slik sykdom kan overvinnes og behandles.

Pasienten har en sykdom eller plage, men for oss å forstå ham/henne best mulig, bør vi foruten å vite om de kroppslige funksjonene, også ha kjennskap til vedkommendes eksistensielle ståsted. Kunnskap om religion, som det kalles, eller eksistensiell orientering, kan være viktig i møtet med pasienten.

Og det er kanskje riktig, som det heter i forordet, som er skrevet av prins Charles, prinsen av Wales (f. 1948), at respekt for både åndelige og fysiske sider ved menneskers liv er spesielt sterk i islam. I hvert fall ligger det i forfatternes intensjon å gjøre behandleren bedre kjent med den religio- nen. Forfatterne forsøker videre å motvirke fordommer, feiloppfatninger og stereotypier som noen hver kan ha med seg, i møte med muslimer.

Boken gir et godt utgangspunkt for dette. Forfatterne presenterer grunnleggende kunnskaper i en lettlest og oversiktlig form. Den inneholder også korte kasuistikker og anekdoter som på en god måte illustrerer de poengene og den kunnskapen som blir lagt frem.

Jeg anbefaler boken. Den bør leses av enhver behandler som omgås muslimske pasienter, og som ikke allerede har godt kjennskap til islam. Kun én innvending kan jeg anføre. Boken kan i sin fremstilling av islam gi leseren et inntrykk av en religion, eller et eksistensielt system, som vil kunne virke tradisjonelt og statisk. Dynamikken i troen og systemet, som gjør den til en utfordring også i dag, kommer ikke klart nok frem. I den sammenhengen kan stoffet stå i fare for å underbygge stereotypier, i stedet for å motvirke dem. Ellers er det spennende lesning.

\section{Trond Ali Linstad}

Urtehagen legekontor

Oslo

\section{Subspesialisert anestesi}

Ian Shaw, Chandra Kumar, Chris Dodds, red.

Oxford textbook of anaesthesia for oral and maxillofacial surgery

337 s, tab, ill. Oxford: Oxford University Press, 2010. Pris GBP 95

ISBN 978-0-19-956421-7

Dette er en ny, oppdatert, rikt illustrert og informativ lærebok

om anestesi for maxillofacial kirurgi og tannbehandling. De kirurgiske behandlingsmetodene spenner derfor over flere subspesialiserte områder i norsk medisin og kan ha interesse for flere kirurgiske spesialiteter, tannleger så vel som anestesileger.

I det forste kapitlet, The history of dental anaesthesia, gir forfatterne en interessant og meget leseverdig beskrivelse av anestesiologiens historie. Videre presenterer de lærebokkapitler med oversikt over pre-anestesiologisk vurdering, luftveissikring, trakeotomi, regionalanestesiteknikker, smertetilstander osv. - alt med spesiell relevans for disse pasientkategoriene og typene inngrep. Kapitlene er skrevet av forfattere med ulik spesialkompetanse. Redaktørene har lykkes bra med å uniformere kapitlene, og det er liten grad av overlapping eller åpenbare motsigelser. Når et tema dekkes dobbelt opp i to kapitler, virker det på meg som om det er riktig og fornuftig. Da kan leseren kan velge å lese ett kapittel og finne utfyllende og tilstrekkelig informasjon om alle relevante aspekter innen kapitlets tema. Referansene er relevante og nye, ja faktisk helt opptil 2009. Jeg oppfatter boken som faglig oppdatert, dog med forbehold om at jeg ikke har tilstrekkelig oversikt innenfor alle fagfelt som dekkes. Alle forfatterne er britiske. Den språklige kvaliteten er god, av og til underholdende god.

Redaktørene har lagt stor vekt på at innholdet skal være forskningsbasert. Det er ingen tvil om at boken gjennomsyres av vurderinger rundt nivå av vitenskaplige bevis. Imidlertid kan det virke underlig når man i kapitlet om smerter i kjeve og ansikt gjentatte ganger angir om en studie er utført $i$ henhold til CONSORT-retningslinjer eller ikke. CONSORT (Consolidated Standards of Reporting Trials) er en internasjonalt anerkjent metode for gjennomføring og beskrivelse av randomiserte kontrollerte studier, og de fleste tidsskrifter krever i dag at manuskripter er utarbeidet etter denne malen. I kapitlet om orofacial smerte tror jeg det kunne vært utelatt, ikke minst fordi dette ikke er nevnt i de øvrige kapitlene.

Vil jeg bruke boken i fremtiden? Og vil jeg anbefale den, og i så fall til hvem? Jeg kommer til å plassere den i nærheten av de operasjonsstuene på Rikshospitalet hvor vi utfører øre-nese-hals-kirurgi, plastikkirurgi og avansert ansikts- og kjevekirurgi. Anestesileger og alle kirurger innen dette fagfeltet vil ha glede av å lese den.

\section{Leiv Arne Rosseland}

Anestesi- og intensivklinikken

Oslo universitetssykehus, Rikshospitalet 